J. Dairy Sci. 99:9287-9299

http://dx.doi.org/10.3168/jds.2016-11253

(C) American Dairy Science Association ${ }^{\circledR}, 2016$.

\title{
Effects of dry period length and dietary energy source on lactation curve characteristics over 2 subsequent lactations
}

\author{
J. Chen, ${ }^{*}$ A. Kok, ${ }^{\star} †$ G. J. Remmelink, J. J. Gross,§ R. M. Bruckmaier,§ B. Kemp, ${ }^{*}$ and A. T. M. van Knegsel ${ }^{* 1}$ \\ *Adaptation Physiology Group, and \\ †Animal Production Systems Group, Department of Animal Sciences, Wageningen University, PO Box 338, 6700 AH Wageningen, \\ the Netherlands \\ fLivestock Research, Wageningen University and Research Center, PO Box 338, 6700 AH Wageningen, the Netherlands \\ $\S$ Veterinary Physiology, Vetsuisse Faculty, University of Bern, Bremgartenstrasse 109a, CH-3012 Bern, Switzerland
}

\section{ABSTRACT}

This study evaluated the effects of dry period (DP) length and dietary energy source on lactation curve characteristics over 2 subsequent lactations. It also evaluated the relationships of energy balance or metabolic status in early lactation with lactation curve characteristics in dairy cows. Holstein-Friesian dairy cows $(\mathrm{n}=$ 167) were assigned randomly to 1 of 3 DP lengths (0-, $30-$, or $60-\mathrm{d}$ ) and 1 of 2 early-lactation diets (glucogenic or lipogenic) for 2 subsequent lactations. In the second lactation following DP length treatments, 19 cows in the 0 - $\mathrm{d}$ DP group were assigned to a $0 \rightarrow 67$-d DP group (actual days dry: $67 \pm 8 \mathrm{~d}$ ). Cows were allocated to this new group when they had a milk yield of $<4 \mathrm{~kg} / \mathrm{d}$ at least $30 \mathrm{~d}$ before their expected calving date. Fat- and protein-corrected milk (FPCM) was calculated weekly per cow in both lactations. Blood samples were taken weekly from calving to wk 4 after calving. A Wilmink lactation curve for each lactation was modeled based on FPCM yield records from calving through 305 DIM. During the first lactation following DP length treatments, cows with a 0- or 30-d DP had lower peak yield, later time of peak yield, and lower $\mathrm{FPCM}_{305}$ than cows with a 60-d DP. In the second lactation following DP length treatments, cows with a 0 - or $30-d$ DP had lower peak yield than cows with a $60-d$ DP. In both lactations, lactation persistency was not affected by DP length and none of the lactation curve characteristics were affected by diet. In parity $>2$ cows, total FPCM yield and average daily FPCM yield throughout 2 lactations did not differ among DP lengths. In addition, average energy balance in the first 4 wk after calving had a negative relationship with peak yield and $\mathrm{FPCM}_{305}$, and a positive relationship with lactation persistency. Average plasma concentrations of free fatty acids and

Received April 1, 2016.

Accepted July 12, 2016.

${ }^{1}$ Corresponding author: Ariette.vanKnegsel@wur.nl $\beta$-hydroxybutyrate had a positive relationship with peak yield and $\mathrm{FPCM}_{305}$, and a negative relationship with lactation persistency. Shortening or omitting the DP affected lactation curve characteristics in both lactations after implementation of DP length treatments but did not compromise FPCM yield compared with a conventional DP of $60 \mathrm{~d}$ in parity $>2$ cows. Severe negative energy balance and poor metabolic status were related to greater peak yield, $\mathrm{FPCM}_{305}$, and lower lactation persistency.

Key words: dry period length, milk yield, lactation persistency, long-term effect

\section{INTRODUCTION}

A dry period (DP) of 6 to $8 \mathrm{wk}$ is an established practice for maximizing milk yield in the subsequent lactation in most dairy farms. This conventional management practice has been applied since the beginning of the past century (Arnold and Becker, 1936) and is likely inappropriate for modern dairy cows because of their increased milk production potential (Zobel et al., 2015). In recent years, interest in shortening the length of the DP for modern dairy cows has increased. Although shortening the DP to about $30 \mathrm{~d}$ or omitting it altogether improves energy balance (Rastani et al., 2005), metabolic status (Chen et al., 2015a), and fertility (Watters et al., 2009) in the first subsequent lactation, a reduction in milk yield hinders the application of this practice. A meta-analysis of 22 studies showed that, compared with a conventional DP (49-63 d), the average milk loss was $4.5 \%$ after a shortened DP (28-35 d) and $19.1 \%$ after omitting the DP (van Knegsel et al., 2013). However, most of these studies investigated effects of the short or omitted DP on milk yield only in the first subsequent lactation immediately following the DP length treatments. It is important to determine the long-term effect of short or omitted DP on milk yield, because sustainable dairy farming implies long-living dairy cows with multiple lactations. In our previous 
study (Chen et al., 2016), we found that differences in milk yield between cows with an omitted DP and cows with a conventional DP were less pronounced in the first 9 wk of the second subsequent lactation compared with the first subsequent lactation after implementation of DP length treatments $(5.0$ vs. $9.6 \mathrm{~kg} / \mathrm{d}$ for the second vs. first subsequent lactation, respectively). Therefore, it is possible that omitting the DP for 2 subsequent lactations results in less 305-d milk yield losses in the second subsequent lactation than in the first.

A lactation curve is a graphical representation of daily milk yield during a complete lactation and is widely used to determine the effects of management (Vance et al., 2012; Steeneveld et al., 2013) and metabolic disorders (Wittrock et al., 2011; Hostens et al., 2012) on milk yield. The shape of a lactation curve is characterized by an increase from initial milk yield directly after calving to peak yield (PY), and a decrease after PY to the end of lactation (lactation persistency, LP). To our knowledge, only 2 studies are available concerning the effects of shortening or omitting the DP on lactation curve characteristics in the first subsequent lactation, and the results are conflicting. Mantovani et al. (2010) reported that omitting the DP resulted in an earlier time of peak yield (PT), lower PY, and lower LP in a small study $(\mathrm{n}=17)$. In contrast, Atashi et al. (2013) found that a shortened DP (0 to $35 \mathrm{~d}$ ) was associated with later PT, lower PY, and higher LP in a field study, compared with a conventional DP (50 to $60 \mathrm{~d}$ ). Neither study investigated the effects of DP length on lactation curve characteristics in multiple lactations.

Recently, Hostens et al. (2012) showed in a field study that cows with 1 or more metabolic disorders in early lactation had a lower PY, a delayed PT, and a higher LP than healthy cows. It can be hypothesized that not only metabolic disease itself, but also metabolic status, indicated by plasma metabolites and metabolic hormones, is related to lactation curve characteristics. Indeed, increased blood free fatty acid and BHB concentrations in early lactation have been related to decreased 305-d milk yield (Duffield et al., 2009; Ospina et al., 2010). However, data are scarce concerning the relationships of energy balance or metabolic status with PY, PT, and LP. We also found that a glucogenic diet improved energy balance and metabolic status in early lactation compared with a lipogenic diet (van Knegsel et al., 2007). However, the effects of dietary energy sources on PT, PY, LP, and 305-d milk yield in dairy cows with different DP lengths have not yet been studied.

The primary objective of this study was to evaluate the effects of DP length and dietary energy sources on lactation curve characteristics over 2 subsequent lactations. A further objective was to evaluate the relationships between metabolic status in early lactation and lactation curve characteristics in dairy cows with different DP lengths and early lactation diets.

\section{MATERIALS AND METHODS}

\section{Animals and Experimental Design}

The Institutional Animal Care and Use Committee of Wageningen University approved the experimental protocol. A total of 167 Holstein-Friesian dairy cows (60 primiparous and 107 multiparous) were selected from the Dairy Campus Research dairy herd (WUR Livestock Research, Lelystad, the Netherlands) for this experiment. The selected cows were served by a Holstein sire and met the following selection criteria: (1) having an expected calving interval less than 490 d; (2) having a daily milk yield greater than $16 \mathrm{~kg} / \mathrm{d}$ at $90 \mathrm{~d}$ before the expected calving date; (3) having no mastitis or high SCC $(>250,000$ cells $/ \mathrm{mL})$ at the last 2 test days before drying off. The experimental design, DP lengths, and dietary contrast have been reported previously (van Knegsel et al., 2014). Briefly, dairy cows were blocked by parity, expected calving date, milk yield in previous lactation, and BCS. Within blocks, cows were assigned randomly to 1 of $3 \mathrm{DP}$ lengths (0-, 30-, or 60-d) and 1 of 2 early lactation diets (glucogenic or lipogenic). The calving intervals during previous lactations before initiation of the experiment were $390 \pm 5 \mathrm{~d}, 398 \pm 6 \mathrm{~d}$, and $396 \pm 7 \mathrm{~d}$ (means \pm $\mathrm{SEM}$ ) for cows with a $0-, 30-$, or $60-\mathrm{d}$ DP, respectively. The milk yields during the lactation before initiation of the experiment were $32.8 \pm 0.6 \mathrm{~kg} / \mathrm{d}, 32.8 \pm 0.6 \mathrm{~kg} / \mathrm{d}$, and $32.8 \pm 0.5 \mathrm{~kg} / \mathrm{d}$ (means $\pm \mathrm{SEM}$ ) for cows with a 0-, 30-, or 60-d DP, respectively. Before calving, dry cows were fed a dry cow diet, and lactating cows were fed a lactation diet supporting $25 \mathrm{~kg}$ of milk. All cows were fed $1 \mathrm{~kg} / \mathrm{d}$ of glucogenic or lipogenic concentrate from $10 \mathrm{~d}$ before the expected calving date. From calving to 100 DIM, the concentrate supply was increased stepwise by $0.5 \mathrm{~kg} / \mathrm{d}$ until it reached $8.5 \mathrm{~kg} / \mathrm{d}$ at 17 DIM. After 100 DIM, all cows were fed the standard lactation concentrate. The main ingredient for the glucogenic concentrate was corn, and the main ingredients for the lipogenic concentrate were sugar beet pulp, palm kernel, and rumen-protected palm oil. Forage was offered ad libitum throughout the study and was composed of grass silage, corn silage, wheat straw, and rapeseed meal or soybean meal (51:34:2:13, DM basis). Cows were housed in a free stall with a slatted floor and cubicles. During lactation, cows were milked twice daily (0500 and $1630 \mathrm{~h})$. Cows with a 30- or 60-d DP were treated with an intramammary antibiotic at drying off (Supermastidol; Virbac Animal Health, Barneveld, the Netherlands). 
Cows were planned to have the same DP length and diet over 2 subsequent lactations. During the first lactation following DP length treatments, 17 cows with a 0 -d DP, 14 cows with a $30-d$ DP, and 6 cows with a $60-d$ DP were excluded from experiment because of fertility or health problems. The second lactation started with 130 cows (39 cows with a $0-d$ DP, 41 cows with a $30-d$ $\mathrm{DP}$, and 50 cows with a $60-\mathrm{d}$ DP). However, 19 cows in the 0 -d DP group were assigned to a $0 \rightarrow 67 \mathrm{~d}$ DP group (actual days dry: $67 \pm 8 \mathrm{~d}$ ). Cows allocated to this new group were dried off without intramammary antibiotics when they had a milk yield of $<4 \mathrm{~kg} / \mathrm{d}$ at least $30 \mathrm{~d}$ before their expected calving date.

\section{Fat- and Protein-Corrected Milk Yield, Composition, and Lactation Curves}

Milk yield was recorded daily per cow throughout 2 subsequent lactations. Milk samples for fat, protein, lactose, and SCC analysis (ISO 9622, Qlip, Zutphen, the Netherlands) were collected 4 times per week and averaged per week. Fat- and protein-corrected milk $($ FPCM $)$ yield was calculated as $[(0.337+0.116 \times$ fat $\%+0.06 \times$ protein $\%) \times$ milk yield $(\mathrm{kg} / \mathrm{d})](\mathrm{CVB}$, 2012). A lactation curve for each lactation was modeled using the exponential model described by Wilmink (1987):

$$
\mathrm{Yt}=\mathrm{a}+\mathrm{b} \times \mathrm{t}+\mathrm{c} \times \exp (-\mathrm{k} \times \mathrm{t})
$$

where Yt is the FPCM yield of a cow at t DIM, a is a regression coefficient related to maximum daily level of production, $\mathrm{b}$ is a regression coefficient related to the rate of FPCM yield decrease after PY, $\mathrm{c}$ is a regression coefficient related to the rate of FPCM yield increase toward PY, and $\mathrm{k}$ is a factor related to the time of PT. In the present analysis, $\mathrm{k}$ was estimated on the whole data set with a nonlinear regression model for the first and second subsequent lactations separately, and fixed for further analyses $(\mathrm{k}=0.06$ for the first subsequent lactation and $\mathrm{k}=0.07$ for the second subsequent lactation). Parameters were estimated based on FPCM yield records from calving through 305 DIM for each lactation. Cows with FPCM yield records less than 260 DIM were excluded to ensure accurate estimates $(\mathrm{n}=8,4$, and 1 for cows with a $0-, 30-$, or 60-d DP in the first subsequent lactation and $\mathrm{n}=3,7,6$, and 2 for cows with a $0-, 30-, 60-$, or $0 \rightarrow 67-\mathrm{d}$ DP in the second subsequent lactation). Cows with a positive estimated value of c, which implied that PY occurred before calving, were excluded from the analysis $(\mathrm{n}=1,5$, and 7 for cows with a $0-, 30-$, or $60-\mathrm{d}$ DP in the first subsequent lactation and $\mathrm{n}=1,4,2$, and 0 for cows with a $0-, 30$-, $60-$, or $0 \rightarrow 67-\mathrm{d}$ DP in the second subsequent lactation).
Time of PY was estimated using the first derivative of the Wilmink function, and PY was the FPCM yield at PT. The cumulative $305-\mathrm{d}$ FPCM yield $\left(\mathbf{F P C M}_{305}\right)$ was calculated by summing the estimated daily FPCM yield from calving until 305 DIM. Estimated FPCM yield was set to 0 when it was negative.

The FPCM yield in the last $60 \mathrm{~d}$ pre-calving $\left(\right.$ FPCM $\left._{-60}\right)$ was actual FPCM yield produced in the last $60 \mathrm{~d}$ pre-calving. The 365-d FPCM yield $\left(\mathbf{F P C M}_{365}\right)$ was calculated by summing $\mathrm{FPCM}_{305}$ and FPCM $_{-60}$. Lactation persistency was calculated as daily milk reduction $(\mathrm{kg} / \mathrm{d})$ by dividing the difference in estimated FPCM yield at 260 DIM and 100 DIM by $160 \mathrm{~d}$.

The cumulative FPCM yield from calving in the first lactation following DP length treatments through $60 \mathrm{~d}$ before the calving in the second lactation $\left(\mathbf{F P C M} \mathbf{C M}_{1 \mathrm{st}}\right)$ was calculated by summing estimated daily FPCM yield from calving in the first lactation through $60 \mathrm{~d}$ before calving in the second lactation (for cows with calving interval $<365$ d) or by summing $\mathrm{FPCM}_{305}$ in the first lactation and actual FPCM yield from $305 \mathrm{~d}$ in the first lactation through $60 \mathrm{~d}$ before calving in the second lactation (for cows with calving interval $>365$ d). The total FPCM yield in 2 subsequent lactations was calculated by summing FPCM yield from 3 periods: (1) the FPCM $_{-60}$ in the first lactation; (2) the $\mathrm{FPCM}_{1 \mathrm{st}}$ in the first lactation; and (3) the 365-d FPCM yield in the second lactation. The average daily FPCM yield in 2 subsequent lactations was calculated by dividing the total FPCM yield by the number of days from 60 $\mathrm{d}$ before calving in the first lactation to $305 \mathrm{~d}$ after calving in the second lactation.

\section{Energy Balance}

Energy balance calculation has been reported previously (van Knegsel et al., 2014). Briefly, energy balance was calculated per wk according to the Dutch VEM system (Van Es, 1975; CVB, 2005) as the difference between VEM supplied with feed and VEM required for maintenance and milk yield.

\section{Blood Sampling and Analysis}

Blood sampling and analysis has been reported previously (Chen et al., 2015a). Briefly, blood samples were taken weekly from 95 cows in the first subsequent lactation and from 113 cows in the second subsequent lactation from calving to $4 \mathrm{wk}$ post-calving. Plasma samples were analyzed for indicators of metabolic status. Concentration of glucose was measured using commercial kit no. 61269 from BioMérieux (Marcy l'Etoile, France). Concentrations of free fatty acid and BHB 
were measured enzymatically using kit no. 994-75409 from Wako Chemicals (Neuss, Germany) and kit no. RB1007 from Randox Laboratories (Ibach, Switzerland), respectively. Insulin and IGF-1 were measured using kit no. A15729 from Beckman Coulter (Fullerton, CA) and kit no. PI-12K from EMD Millipore Corporation (Billerica, MA), respectively.

\section{Statistical Analysis}

The PROC MIXED procedure of SAS (version 9.2; SAS Institute, Inc., Cary, NC) was performed to analyze the effect of DP length and dietary energy source on lactation curve characteristics for the first and second subsequent lactations separately. Fat- and proteincorrected milk yield, PT, PY, and LP were analyzed with DP length (0-, 30-, or 60-d for the first subsequent lactation; 0-, 30-, 60-, or $0 \rightarrow 67$-d for the second subsequent lactation), diet (glucogenic or lipogenic), parity ( 2 or $>2$ for the first subsequent lactation; 3 or $>3$ for the second subsequent lactation), and their 2-way interactions included as fixed effects. Nonsignificant interactions were excluded from the model via backward stepwise elimination if $P>0.05$. For the analyses of the first lactation, preliminary analyses showed that the interaction of DP length with diet was not significant $(P>0.05)$. For the second lactation, preliminary analyses showed that interactions of diet with DP length and diet with parity were not significant $(P>0.05)$. For average daily FPCM yield in 2 subsequent lactations, preliminary analyses showed that interactions of diet with DP length and diet with parity were not significant $(P>0.05)$. For comparison of DP lengths, $P$-values were presented after a Tukey's adjustment. Values were presented as least squares means with their standard errors.

To determine the relationships between metabolic status and lactation curve characteristics (PY, PT, $\mathrm{LP}$, and $\mathrm{FPCM}_{305}$ ), data from the first and second subsequent lactations were combined (243 lactations in total). Data were analyzed as repeated measurements with cow as the subject. A compound symmetry covariance structure was the best fit and was used to account for within-cow variation. Dry period length $(0-, 30-$, 60 -, or $0 \rightarrow 67-d$ ), parity ( 2 or $>2$ ), and interactions of DP length or parity with metabolic variables were included as fixed effects. Average energy balance, plasma concentrations of free fatty acids, BHB, glucose, IGF-1, or insulin in the first $4 \mathrm{wk}$ after calving were included as covariates in the model one by one to obtain regression coefficients $(\beta)$. To determine the relationships between PY, PT, LP, and $\mathrm{FPCM}_{305}$, DP length, parity, and interactions of DP length or parity with lactation curve characteristics were included as fixed effects.
Peak yield, PT, and LP were included as covariates in the model one by one to obtain regression coefficients $(\beta)$. A preliminary backward stepwise regression was performed for each analysis, and nonsignificant interactions $(P>0.05)$ were excluded from the model.

\section{RESULTS}

\section{Actual DP Length}

Actual days dry before calving in the first subsequent lactation were $2 \pm 1 \mathrm{~d}, 30 \pm 1 \mathrm{~d}, 64 \pm 2 \mathrm{~d}$, and $61 \pm$ $1 \mathrm{~d}$ (means \pm SEM) for cows with a $0-, 30-$, or 60 -d DP, respectively. Actual days dry before calving in the second subsequent lactation were $0 \pm 0 \mathrm{~d}, 42 \pm 7 \mathrm{~d}, 65$ $\pm 2 \mathrm{~d}$, and $67 \pm 8 \mathrm{~d}$ (means \pm SEM) for cows with a 0 -, 30-, 60-, or $0 \rightarrow 67$-d DP, respectively.

\section{FPCM Yield, PY, PT, and LP in the First Lactation Following DP Length Treatments}

In the first lactation following DP length treatments, cows with a 0-d DP had lower $\mathrm{FPCM}_{305}$ and PY, but greater $\mathrm{FPCM}_{-60}$ than cows with a $60-\mathrm{d} \mathrm{DP}$; cows with a 30-d DP were intermediate (Table 1). Cows with a 0-d DP had lower $\mathrm{FPCM}_{365}$ than cows with a 30- or 60-d DP. Cows with a 30- or 60-d DP had similar $\mathrm{FPCM}_{365}$. Cows with a 0-d DP had later PT than cows with a 60-d DP. Lactation persistency was not affected by DP length, and none of the lactation curve characteristics were affected by diet.

An interaction of DP length $\times$ parity was present for $\mathrm{FPCM}_{305}, \mathrm{FPCM}_{-60}$, and PY. In parity $=2$ cows, cows with a 0-d DP produced 3,067 $\mathrm{kg}$ less $\mathrm{FPCM}_{305}$ and had a $10.9 \mathrm{~kg}$ lower PY than cows with a $60-\mathrm{d}$ DP $(P<$ $0.01)$. In parity $>2$ cows, cows with a $0-d$ DP produced $1,937 \mathrm{~kg}$ less $\mathrm{FPCM}_{305}$ and had a $6.3 \mathrm{~kg}$ lower PY than cows with a $60-\mathrm{d}$ DP $(P<0.01)$. In addition, omitting the DP resulted in more $\mathrm{FPCM}_{-60}(1,226$ vs. $884 \mathrm{~kg}$, $P<0.01)$ in parity $=2$ cows than in parity $>2$ cows. Furthermore, $\mathrm{FPCM}_{305}$ was lower for cows with a 30-d DP than cows with a $60-d$ DP in parity $>2$ cows $(9,261$ vs. $10,601 \mathrm{~kg}, P=0.04)$, but not in parity $=2$ cows $(P$ $=0.55)$.

\section{FPCM Yield, PY, PT, and LP in the Second Lactation Following DP Length Treatments}

In the second lactation following DP length treatments, cows with a 0- or 30-d DP had greater FPCM -60 than cows with a 60 - or $0 \rightarrow 67$-d DP (Table 2). Cows with a 0- or 30-d DP had lower PY, and cows with a 0 -d DP tended to have lower $\operatorname{FPCM}_{305}(P=0.09)$ 
EFFECTS OF DRY PERIOD LENGTH ON LACTATION CURVE
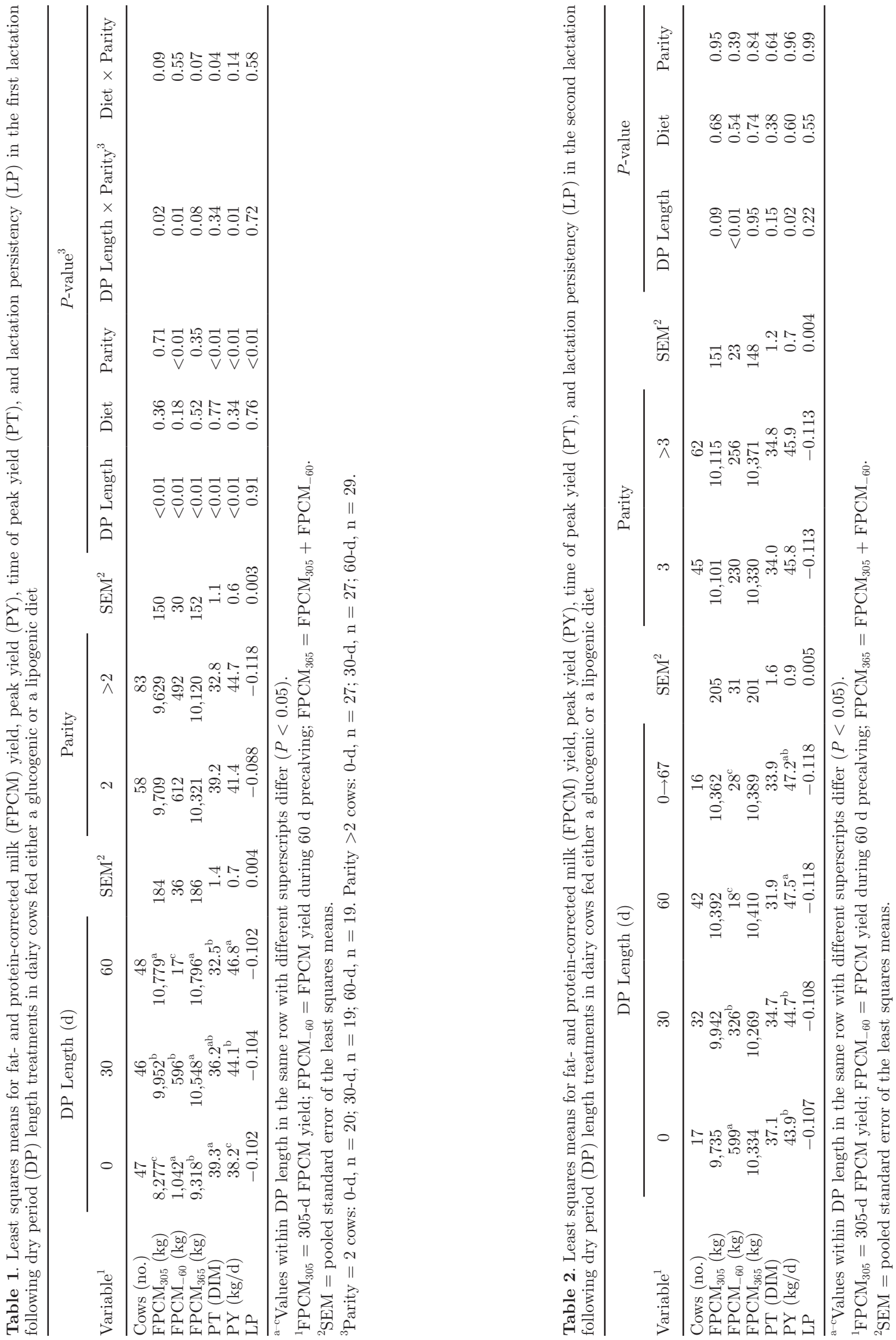
than cows with a 60-d DP. Lactation persistency and $\mathrm{FPCM}_{365}$ were not affected by DP length. None of the lactation curve characteristics were affected by diet or parity.

\section{Average Daily FPCM Yield Throughout 2 Subsequent Lactations}

Throughout 2 subsequent lactations following DP length treatments, total FPCM yield and average daily FPCM yield were not different among cows with a 0-, $30-$, or 60 -d DP (Table 3 ). Cows with a $0 \rightarrow 67$-d DP had lower total and average daily FPCM yields than cows with a 30- or 60-d DP. Concerning the first lactation, cows with a 0 - or $0 \rightarrow 67$-d DP had lower $\mathrm{FPCM}_{1 \mathrm{st}}$ than cows with a 30- or 60-d DP. An interaction of DP length $\times$ parity was present for total FPCM yield and average daily FPCM yield throughout 2 subsequent lactations. In parity $=2$ cows, cows with a 0 - or $0 \rightarrow 67$-d DP had lower total FPCM yield than cows with a 30- or 60 -d DP (Figure $1 \mathrm{~A}$ ), and cows with a $0 \rightarrow 67$-d DP had lower average daily FPCM yield than cows with a 30- or 60-d DP (Figure 1 B). In parity $>2$ cows, we observed no effect of DP length on total FPCM yield $(P=0.49)$ and average daily FPCM yield $(P=0.50)$.

\section{Relationships Between PY, PT, LP, and FPCM 305}

When 2 subsequent lactations following DP length treatments were combined, PT had a positive relationship with LP $(\beta=0.0006 ; P<0.01)$. Peak yield had a negative relationship with LP $(\beta=-0.003 ; P<0.01)$ and a positive relationship with $\mathrm{FPCM}_{305}(\beta=217 ; P$ $<0.01$ ). Interactions of $\mathrm{PY} \times \mathrm{DP}$ length were present for LP (Figure $2 \mathrm{~A}, P<0.01$ ) and $\mathrm{FPCM}_{305}$ (Figure 2 $\mathrm{B}, P<0.01)$. No correlation was found between LP and $\mathrm{FPCM}_{305}(P=0.66)$.

\section{Relationships of Energy Balance or Metabolic Status with FPCM Lactation Curve Characteristics}

Average energy balance and plasma insulin concentration in the first $4 \mathrm{wk}$ after calving had a positive relationship with $\mathrm{PT}$, whereas average plasma free fatty acid concentration in the first 4 wk after calving had a negative relationship with PT (Table 4). Average energy balance and plasma concentrations of glucose, insulin, and IGF-1 in the first 4 wk after calving had a negative relationship with PY and $\mathrm{FPCM}_{305}$. Average plasma free fatty acid and BHB concentrations in the first $4 \mathrm{wk}$ after calving had a positive relationship with $\mathrm{PY}$ and $\mathrm{FPCM}_{305}$. In addition, average energy balance in the first $4 \mathrm{wk}$ after calving had a positive relationship with LP, whereas average plasma free fatty acid

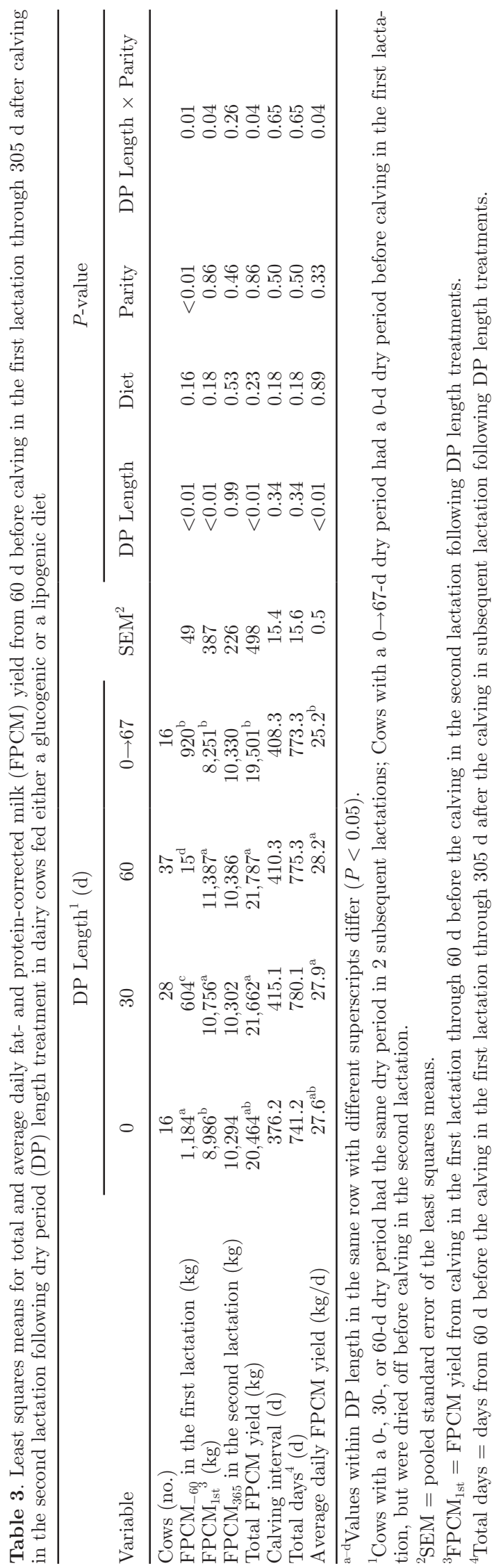


and BHB concentrations in the first 4 wk after calving had a negative relationship with LP.

Interactions of IGF- $1 \times$ parity (Figure $3 \mathrm{~A}$ ) and IGF$1 \times$ DP length (Figure $4 \mathrm{~A}$ ) were present for PT. A negative relationship between plasma IGF-1 concentration and PT was present in cows with a $0 \rightarrow 67$-d DP $(P$ $=0.02)$ or parity $=2$ cows $(P=0.01)$, but not in cows with other DP lengths or parity $>2$ cows.

Interactions of free fatty acids $\times$ DP length (Figure $4 \mathrm{~B})$ and IGF- $1 \times$ DP length (Figure $4 \mathrm{C}$ ) were present for PY. A positive relationship between plasma free

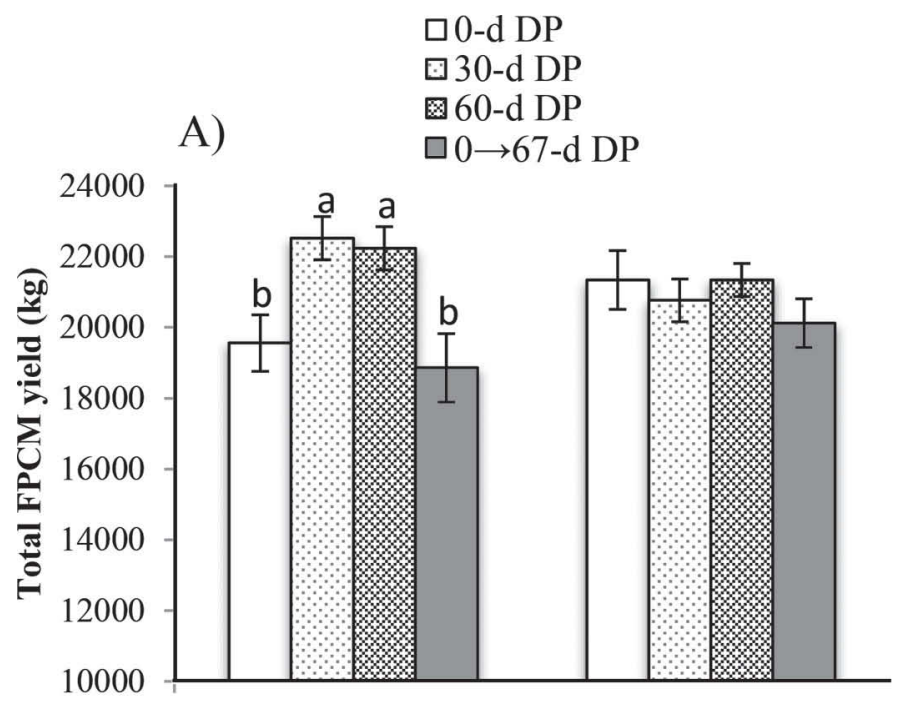

B)

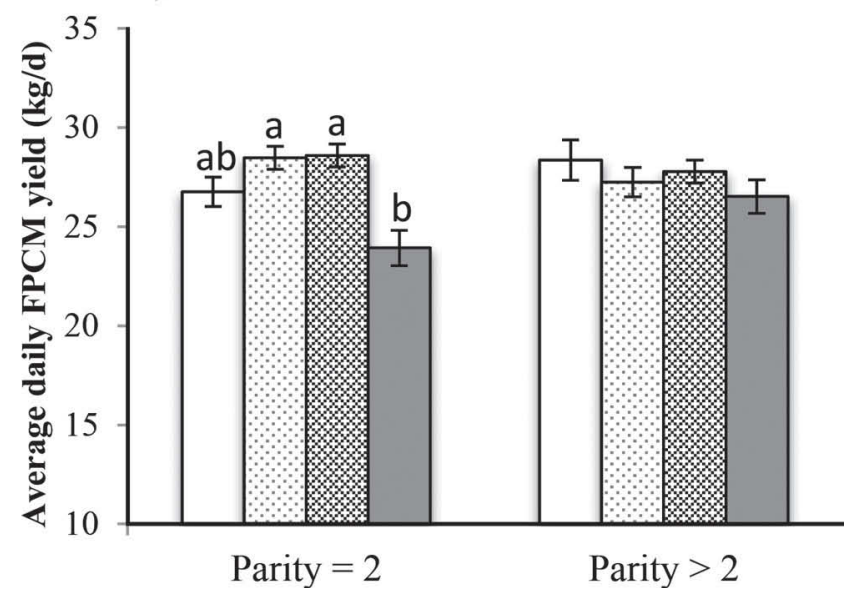

Figure 1. (A) Total fat- and protein-corrected milk (FPCM) yield from $60 \mathrm{~d}$ before calving in the first lactation through $305 \mathrm{~d}$ after calving in the second lactation in parity $=2$ and parity $>2$ cows after a dry period (DP) of $0,30,60$, or $0 \rightarrow 67$ d. (B) Average daily FPCM yield from $60 \mathrm{~d}$ before calving in the first lactation through $305 \mathrm{~d}$ after calving in the second lactation in parity $=2$ and parity $>2$ cows after a DP of $0,30,60$, or $0 \rightarrow 67 \mathrm{~d}$. Values represent LSM ( \pm SEM) per treatment per parity class; bars with different letters (a, b) within parity differ $(P<0.05)$. fatty acid concentration and PY was present in cows with a 0 - or $30-\mathrm{d}$ DP $(P<0.01)$, but not in cows with a 60 - or $0 \rightarrow 67$-d DP. A negative relationship between plasma IGF-1 concentration and PY was only present in cows with a 0 -d DP $(P<0.01)$.

Interactions of energy balance $\times$ DP length (Figure 4 $\mathrm{D})$, free fatty acids $\times$ DP length (Figure $4 \mathrm{E}$ ), $\mathrm{BHB} \times$ DP length (Figure $4 \mathrm{~F}$ ), glucose $\times$ DP length (Figure $4 \mathrm{G}$ ), glucose $\times$ parity (Figure $3 \mathrm{~B}$ ), free fatty acids $\times$ parity (Figure $3 \mathrm{C}$ ), and IGF-1 $\times$ DP length (Figure $4 \mathrm{H})$ were present for $\mathrm{FPCM}_{305}$. Negative relationships between energy balance and $\mathrm{FPCM}_{305}(P<0.01)$, and between plasma glucose concentration and $\mathrm{FPCM}_{305}$

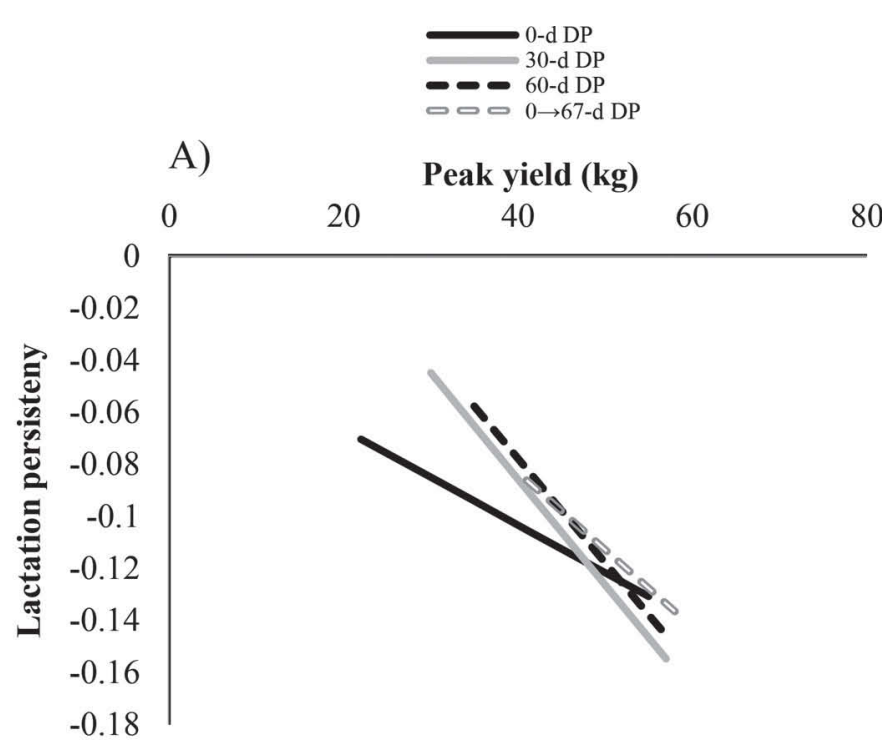

B)

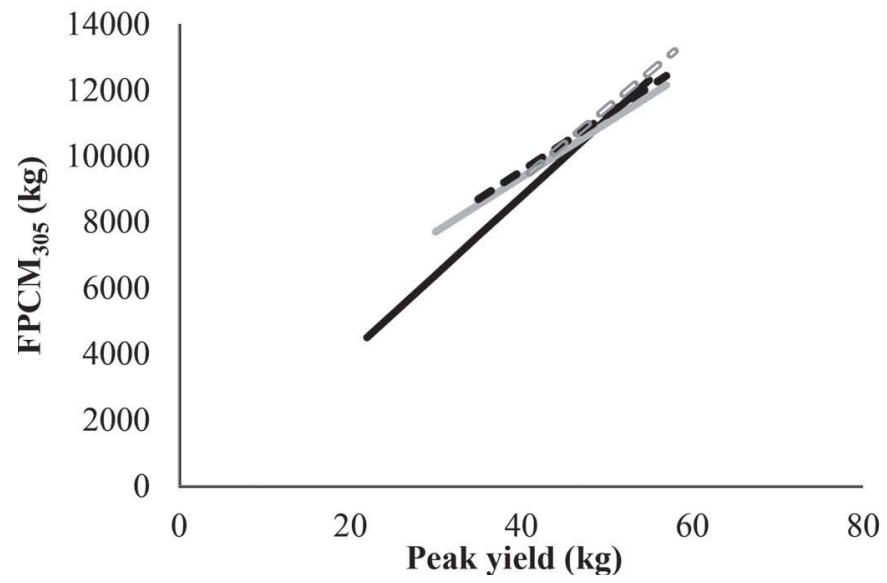

Figure 2. Estimated associations of peak yield with lactation persistency (A), and peak yield with 305-d fat- and protein-corrected milk $\left(\mathrm{FPCM}_{305}\right.$; B) in cows with a $0-, 30-, 60-$, or $0 \rightarrow 67$-d dry period (DP). The values of estimated peak yield were truncated according to actual minimum and maximum values in each DP length group. 
$(P<0.01)$, as well as a positive relationship between plasma free fatty acid concentration and $\mathrm{FPCM}_{305}$ $(P<0.05)$, were present in cows with a $0-, 30-$, or $0 \rightarrow 67$-d DP, but not in cows with a 60 -d DP. A positive relationship between plasma $\mathrm{BHB}$ concentration and $\mathrm{FPCM}_{305}$ was present in cows with a 0 - or $0 \rightarrow 67$-d DP $(P=0.04)$, but not in cows with other DP lengths. A negative relationship between plasma IGF-1 concentration and $\mathrm{FPCM}_{305}$ was present in cows with a 0 -d DP $(P<0.01)$, but not in cows with other DP lengths.

\section{DISCUSSION}

In the present study, shortening or omitting the DP resulted in later PT, lower PY, lower $\mathrm{FPCM}_{305}$, and no effect on LP in 2 subsequent lactations after implementation of DP length treatments. Peak yield was positively correlated with $\mathrm{FPCM}_{305}$, but no correlation was found between $\mathrm{LP}$ and $\mathrm{FPCM}_{305}$. This implies that $\mathrm{FPCM}_{305}$ yield losses after a 0- or 30-d DP compared with a 60-d DP were not related to LP in dairy cows. Atashi et al. (2013) found an increased LP after a shortened (0 to 35 d) DP compared with a conventional (51 to $60 \mathrm{~d}$ ) DP in primiparous cows in a field study. In that field study, cows were not planned to have a shorter DP and cows with high persistency were probably those with a longer lactation period (shorter DP) due to greater milk yield in late lactation. This could explain the increased LP in cows with a short DP in Atashi et al. (2013). In contrast, Mantovani et al. (2010) reported that omitting the DP decreased LP. In that study, cows with a conventional or omitted DP had PY of 36.8 and $31.3 \mathrm{~kg}$, respectively, and LP of
-0.062 and -0.078 , respectively. The differences in the effects of DP length on LP between our study and this previous finding might be related to the relatively low PY and high LP in dairy cows in Mantovani et al. (2010), but further studies are needed to confirm that finding.

The decreased PY and later PT in cows with a 0or 30-d DP could be related to the high proportion of senescent mammary epithelial cells in these cows in early lactation. Capuco et al. (2001) suggested that the increase in milk yield until peak is due to continued differentiation of mammary secretory cells and increased secretory activity per cell in early lactation. Omitting the DP increases carryover of senescent mammary epithelial cells into the subsequent lactation (Capuco et al., 1997; Annen et al., 2007; Annen et al., 2008), which decreases secretory ability of mammary gland cells (Collier et al., 2012). Bernier-Dodier et al. (2011) also suggested that the decreased milk yield after shortening the DP to $35 \mathrm{~d}$ is related to incomplete mammary gland renewal during the DP. In addition, PT had a positive relationship and PY had a negative relationship with LP in the present study. Although cows with a 0- or 30-d DP had decreased PY and later PT, they did not have higher LP than cows with a 60-d DP in both subsequent lactations. It is possible that the high proportion of senescent mammary epithelial cells in cows with a 0- or 30-d DP limited LP when PY decreased.

In the first lactation following DP length treatments, omitting the DP in parity $=2$ cows caused a more pronounced decrease in PY and $\mathrm{FPCM}_{305}$ than in parity $>2$ cows, which is in agreement with Mantovani

Table 4. Regression coefficients $(\beta)$ of energy balance, plasma metabolites, or hormones ${ }^{1}$ related to peak yield (PY), time of peak yield (PT), lactation persistency (LP), and 305-d fat- and protein-corrected milk $\left(\mathrm{FPCM}_{305}\right)$ yield ${ }^{2}$

\begin{tabular}{lcccc}
\hline Variable & $\mathrm{PT}^{3}(\mathrm{DIM})$ & $\mathrm{PY}^{4}(\mathrm{~kg} / \mathrm{d})$ & $\mathrm{LP}$ & $\mathrm{FPCM}_{305}{ }^{5}(\mathrm{~kg})$ \\
\hline Energy balance $^{6}\left(\mathrm{~kJ} / \mathrm{kg}^{0.75} \cdot \mathrm{d}\right)$ & $0.02^{* *}$ & $-0.02^{* *}$ & $0.00006^{* *}$ & $-7.7^{* *}$ \\
Free fatty acids $(\mathrm{mmol} / \mathrm{L})$ & $-7.10^{*}$ & $9.52^{* *}$ & $-0.025^{* *}$ & $2,418.6^{* *}$ \\
BHB $(\mathrm{mmol} / \mathrm{L})$ & 0.42 & $2.03^{* *}$ & $-0.011^{* *}$ & $842.6^{*}$ \\
Glucose $(\mathrm{mmol} / \mathrm{L})$ & 2.23 & $-3.88^{* *}$ & 0.010 & $-1,754.9^{* *}$ \\
IGF-1 $(\mathrm{ng} / \mathrm{mL})$ & -0.16 & $-0.05^{*}$ & 0.00004 & $-22.2^{*}$ \\
Insulin $(\mu \mathrm{IU} / \mathrm{mL})$ & $0.28^{* *}$ & $-0.32^{* *}$ & 0.00051 & $-75.0^{* *}$ \\
\hline
\end{tabular}

${ }^{1}$ Energy balance, plasma concentrations of free fatty acids, BHB, glucose, IGF-1, or insulin were averaged for the first $4 \mathrm{wk}$ in the first or second lactation following dry period (DP) length treatments.

${ }^{2}$ Total lactations for energy balance and SCC: $0-\mathrm{d}, \mathrm{n}=63 ; 30-\mathrm{d}, \mathrm{n}=76 ; 60-\mathrm{d}, \mathrm{n}=86 ; 0 \rightarrow 67-\mathrm{d}, \mathrm{n}=16$. Total lactations for plasma metabolites and hormones: $0-\mathrm{d}, \mathrm{n}=37 ; 30-\mathrm{d}, \mathrm{n}=52 ; 60-\mathrm{d}, \mathrm{n}=59 ; 0 \rightarrow 67-\mathrm{d}, \mathrm{n}=16$.

${ }^{3}$ Interactions of IGF- $1 \times$ DP length $(P=0.02)$ and IGF- $1 \times$ parity $(P=0.02)$ were present.

${ }^{4}$ Interactions of free fatty acids $\times$ DP length $(P=0.04)$, and IGF- $1 \times$ DP length $(P=0.04)$ were present.

${ }^{5}$ Interactions of energy balance $\times$ DP length $(P<0.01)$, free fatty acids $\times$ DP length $(P<0.01)$, BHB $\times$ DP length $(P=0.02)$, glucose $\times$ DP length $(P<0.01)$, IGF-1 $\times$ DP length $(P<0.01)$, free fatty acids $\times$ parity $(P<0.01)$, and glucose $\times$ parity $(P<0.01)$ were present.

${ }^{6}$ Energy balance was calculated using the VEM system (Van Es, 1975).

${ }^{* *} P<0.01 ;{ }^{*} P<0.05$. 


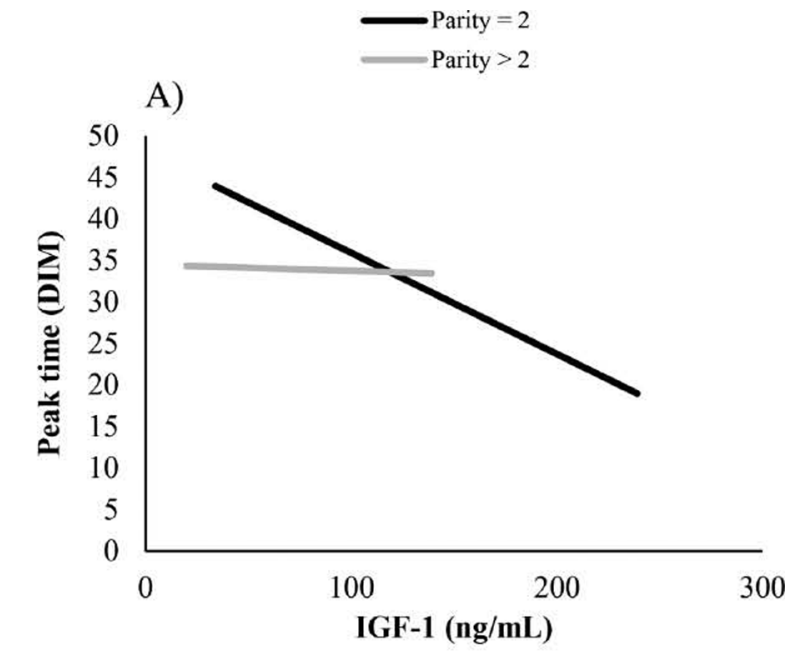

B)

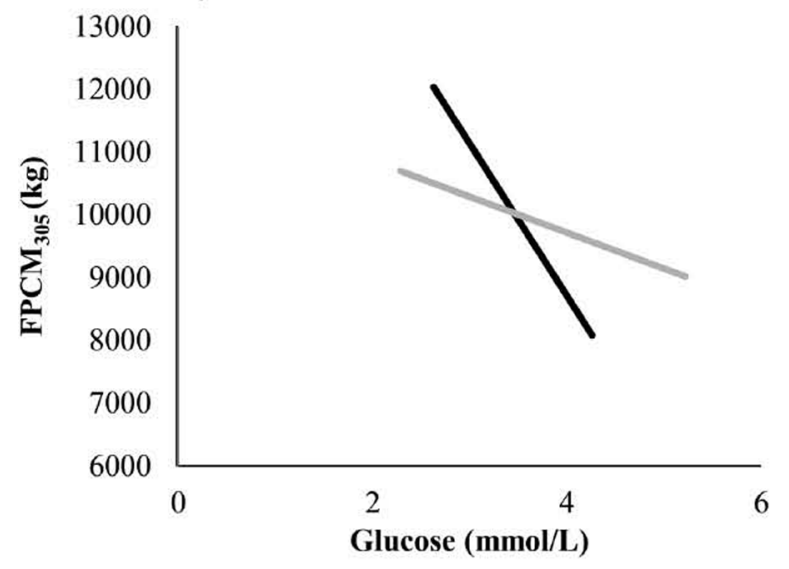

C)

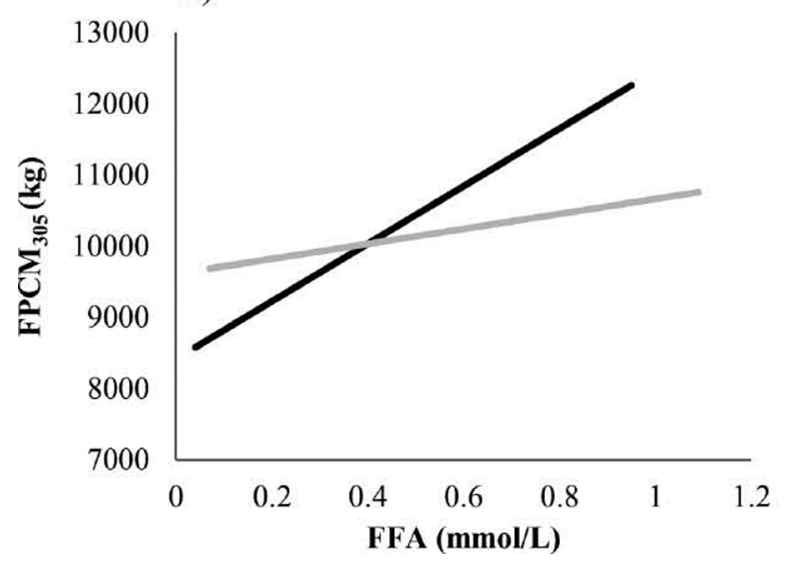

Figure 3. (A) Estimated associations of plasma IGF-1 concentrations with peak time in parity $=2$ or parity $>2$ cows. (B) Estimated associations of plasma glucose concentrations with 305-d fat- and protein-corrected milk $\left(\mathrm{FPCM}_{305}\right)$ in parity $=2$ or parity $>2$ cows. $(\mathrm{C})$ Estimated associations of plasma free fatty acid (FFA) concentrations with 305-d fat- and protein-corrected milk yield $\left(\mathrm{FPCM}_{305}\right)$ in parity $=2$ or parity $>2$ cows. Plasma concentrations of IGF-1, glucose, and FFA were average for the first 4 wk after calving. The values of estimated plasma concentrations of IGF-1, glucose, and FFA were truncated according to actual minimum and maximum values in each parity group. et al. (2010). Collier et al. (2012) suggested that the greater reduction in milk yield in parity $=2$ cows after omitting the DP could be related to greater requirements for both mammary development and mammary epithelial cell turnover between the first and second parity, compared with later parities. This might imply that omitting the DP is less suitable for parity $=2$ cows because of substantial milk yield losses. In addition, Santschi et al. (2011) found in a field study that shortening the DP decreased milk yield in the first subsequent lactation in parity $=2$ cows, but not in parity $>2$ cows. By contrast, in the first lactation following DP length treatments in the present study, shortening the DP decreased $\mathrm{FPCM}_{305}$ compared with conventional DP in parity $>2$ cows, but not in parity $=2$ cows. Taking into account the additional FPCM yield pre-calving, however, shortening the DP resulted in similar $\mathrm{FPCM}_{365}$ compared with a conventional DP in both parity $=2$ and parity $>2$ cows.

In the second lactation following DP length treatments, the difference in PY, PT, and, $\mathrm{FPCM}_{305}$ between cows with a 0 - and 60-d DP were smaller than in the first lactation, although the PY was still lower and $\mathrm{FPCM}_{305}$ tended to be lower in cows with a $0-\mathrm{d}$ DP than cows with a $60-d$ DP. Moreover, FPCM $_{365}$ in cows with a 0-d DP in the second lactation did not differ from that of cows with a 60-d DP (10,334 vs. $10,410 \mathrm{~kg}$ for 0 - vs. 60 -d DP). The smaller differences between cows with a 0 - and $60-\mathrm{d}$ DP on lactation curve characteristics were related to increased PY, $\mathrm{FPCM}_{305}$, $\mathrm{FPCM}_{365}$, and earlier PT in cows with a 0 -d DP in the second lactation, which can be explained by the increased parity in dairy cows in the second lactation. It has been suggested that parity $>2$ cows have less milk yield losses after omitting the DP compared with parity $=2$ cows (Annen et al., 2004; Watters et al., 2008; Chen et al., 2016). A recent field study, nevertheless, demonstrated that omitting the DP resulted in $560 \mathrm{~kg}$ greater $\mathrm{FPCM}_{305}$ in the second subsequent lactation compared with the first subsequent lactation in parity $>2$ cows [A. Kok, A. T. M. van Knegsel, C. E. van Middelaar (Wageningen University, Wageningen, the Netherlands), B. Engel (Wageningen University, Wageningen, the Netherlands), H. Hogeveen (Wageningen University, Wageningen, the Netherlands), B. Kemp, and I. J. M. de Boer (Wageningen University, Wageningen, the Netherlands), unpublished data]. In line with this, omitting the DP in parity $>2$ cows resulted in $1,071 \mathrm{~kg}$ greater $\mathrm{FPCM}_{305}$ in the second lactation compared with the first lactation in the present study. These results imply that increased parity is not the only cause of increased milk yield in the second lactation after omitting the DP. It is possible that increased turnover of mammary epithelial cells during lactation in the first lacta- 

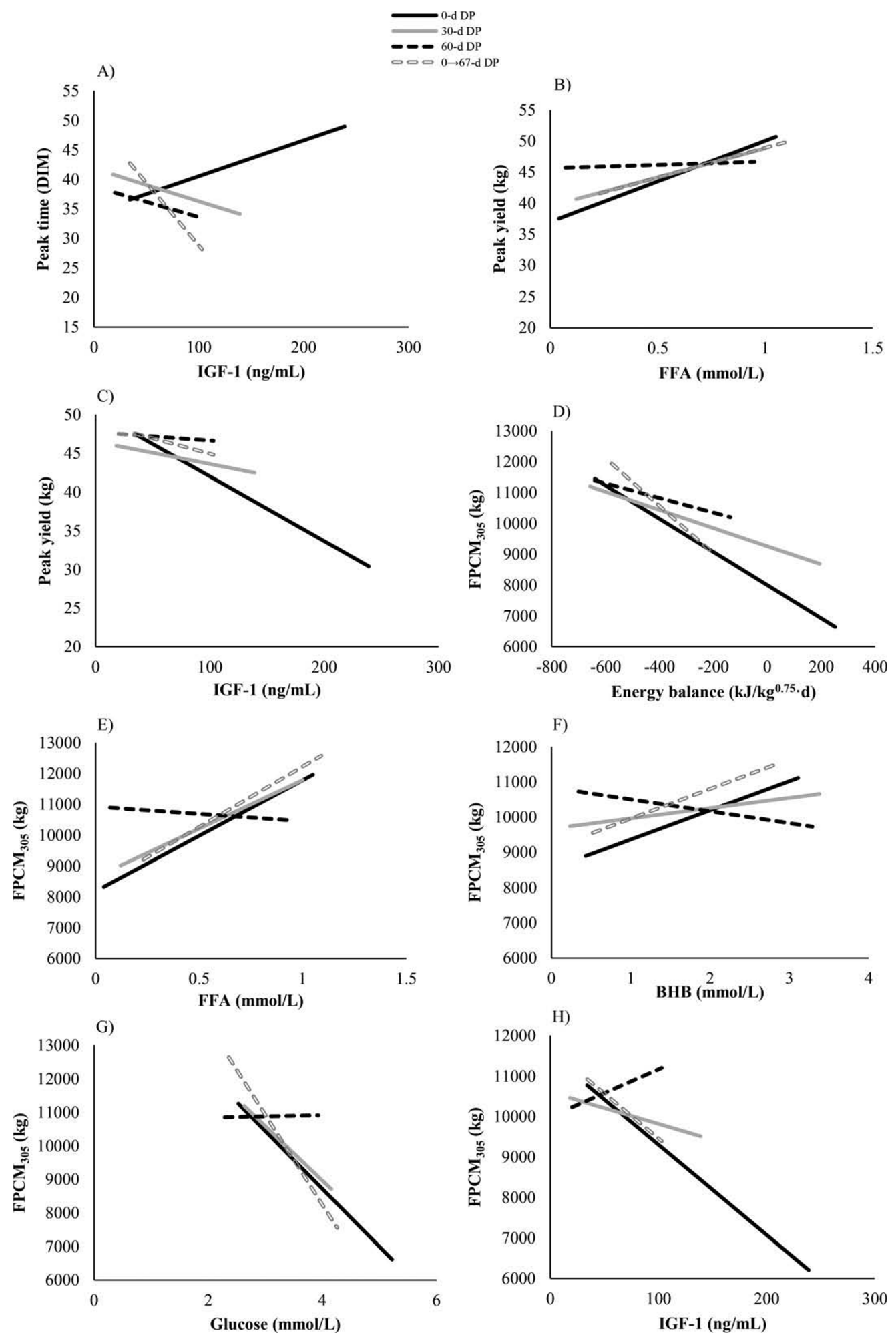

Figure 4. Estimated associations of (A) plasma IGF-1 concentration with time of peak time; (B) plasma free fatty acid (FFA) concentration with peak yield; (C) plasma IGF-1 concentration with peak yield; (D) energy balance with 305-d fat- and protein-corrected milk (FPCM ${ }_{305}$ ); (E) plasma free fatty acid concentration with $\mathrm{FPCM}_{305}$; (F) plasma BHB concentration with $\mathrm{FPCM}_{305}$; (G) plasma glucose concentration with $\mathrm{FPCM}_{305}$; and $(\mathrm{H})$ plasma IGF-1 concentration with $\mathrm{FPCM}_{305}$ in cows with a 0-, 30-, 60-, or 0 $\rightarrow 67-\mathrm{d}$ dry period (DP). Energy balance, plasma concentrations of free fatty acids, IGF-1, glucose, and BHB were average for the first 4 wk after calving. The values of estimated energy balance, plasma concentrations of free fatty acids, IGF-1, glucose, and BHB were truncated according to actual minimum and maximum values in each DP length group. 
tion also plays a role in increased FPCM yield in cows with a 0 -d DP in the second lactation. The turnover of mammary epithelial cells exists throughout lactation (Capuco et al., 2001). It can be hypothesized that the senescent mammary epithelial cells in cows with a $0-d$ DP were replaced with new cells in mid- or late lactation in the first lactation, which increased the secretory capability of the mammary gland in the second.

To our knowledge, only 1 controlled study has reported the effects of omitting the DP on milk yield over 2 subsequent lactations (Remond et al., 1997). The authors found similar milk yield during $36 \mathrm{wk}$ of the second lactation between the experimental (no DP) and control groups (conventional DP of $8 \mathrm{wk}$ ). In that study, however, only 2 of 21 cows assigned to the experimental group had a DP of $0 \mathrm{~d}$ before calving in the second lactation, meaning that most of these cows dried themselves off and in fact had DP of variable length. Herewith, it can be suggested that those cows had more opportunities for replacement of senescent mammary epithelial cells during the pre-calving period. This implies that these cows (Remond et al., 1997) were comparable to cows with a $0 \rightarrow 67$-d DP in the present study, which had similar $\mathrm{FPCM}_{305}, \mathrm{FPCM}_{365}$, and PY than cows with a 60-d DP in the second lactation.

Milk yield in last $60 \mathrm{~d}$ pre-calving in cows with a 0 - or 30-d DP was lower in the second lactation than in the first. A. Kok, A. T. M. van Knegsel, C. E. van Middelaar (Wageningen University, Wageningen, the Netherlands), B. Engel (Wageningen University, Wageningen, the Netherlands), H. Hogeveen (Wageningen University, Wageningen, the Netherlands), B. Kemp, and I. J. M. de Boer (Wageningen University, Wageningen, the Netherlands; unpublished data) found that omission of the DP resulted in $172 \mathrm{~kg}$ lower $\mathrm{FPCM}_{-60}$ in the second lactation compared with the first lactation following DP length treatments in a field study. The decreased PY and unchanged LP in cows with a 0 - or 30-d DP in the first lactation led to decreased FPCM yield in late lactation, which may partly explain decreased $\mathrm{FPCM}_{-60}$ in cows with a 0 - or $30-\mathrm{d}$ DP in the second lactation. In addition, decreased FPCM $_{-60}$ in the second lactation could also be related to the increased parity of these cows. Primiparous cows generally have higher LP than multiparous cows (Miller et al., 2006). In late first lactation, all cows were multiparous, and the lower LP of those multiparous cows resulted in lower FPCM yield before the next lactation.

Kok et al. (2016) have proposed using effective lactation yield instead of traditional 305-d milk yield to compare milk yield among cows with different DP lengths. Effective lactation yield was defined as the daily yield from $60 \mathrm{~d}$ before calving to $60 \mathrm{~d}$ before next calving (Kok et al., 2016). This new approach corrects for dif- ferences in calving interval and possible additional milk yield pre-calving. In the present study, complete data was available for the first lactation, but data from the second lactation stopped at 305 DIM. To correct for differences in calving interval in the first lactation and assess the effect of milk yield over 2 lactations, we compared total FPCM yield and average daily FPCM yield throughout 2 subsequent lactations among DP lengths in the present study.

In parity $>2$ cows, total FPCM yield and average daily FPCM throughout 2 subsequent lactations did not differ among DP lengths. These results suggest that shortening the DP to $30 \mathrm{~d}$ or omitting the DP completely does not compromise FPCM yield compared with a conventional DP of $60 \mathrm{~d}$ in parity $>2$ cows from a long-term perspective. Parity $=2$ cows that were able to milk continuously for 2 subsequent lactations (0-d DP) had lower total FPCM yield over 2 lactations than cows with a 60-d DP. In parity = 2 cows, however, the average daily FPCM yield did not differ between cows with a $0-d$ DP and cows with a 60-d DP. This is because the cows with a $0-d$ DP had relatively fewer total days throughout 2 subsequent lactations than cows with a $60-d$ DP, due to a shorter calving interval ( 376.2 vs. 415.1 vs. 410.3 vs. $408.3 \mathrm{~d}$ for $0-, 30-, 60-$, and $0 \rightarrow 67-d \mathrm{DP})$. To our knowledge, the present study is the first reporting average daily FPCM yield throughout 2 subsequent lactations after different DP lengths. Considering the beneficial effects on energy balance (Rastani et al., 2005), metabolic status (Chen et al., 2015a), and fertility (Watters et al., 2009; Chen et al., 2015b), shortening or omitting the DP can be a practical management strategy with no milk yield losses in parity $>2$ cows from a long-term perspective.

In the present study, elevated plasma free fatty acid concentration, decreased energy balance, and decreased plasma glucose concentration were related to increased $\mathrm{FPCM}_{305}$ in cows with a 0 - or $30-\mathrm{d} \mathrm{DP}$, but not in cows with a $60-d$ DP. In cows with a 0 - or 30-d DP, highproducing cows partition more energy to milk and, therefore, cause more severe negative energy balance and more pronounced body fat mobilization, related to increased plasma concentrations of free fatty acids and BHB (Chen et al., 2015a). Cows with a 60-d DP, however, had greater milk yield, more severe negative energy balance, and greater plasma free fatty acid and BHB concentrations than cows with a 0- or 30-d DP, especially in the first lactation following DP length treatments in the present study (van Knegsel et al., 2014; Chen et al., 2015a), increasing the risk of metabolic disorders. In earlier studies, cows that encountered 1 or more metabolic disorders (ketosis, milk fever, and displaced abomasum) had lower PY, lower 305-d milk yield, and higher LP (Appuhamy et al., 2007; Hostens 
et al., 2012). In the present study, cows with a 60-d DP had a more severe negative energy balance and greater plasma concentrations of free fatty acids and BHB than cows with other DP lengths, related to an increased risk of metabolic disorders. Therefore, the relationships of energy balance and metabolic status with $\mathrm{FPCM}_{305}$ in cows with a 60-d DP may be influenced by metabolic disorders, which could partly explain the lack of relationships in these cows in our study. Furthermore, elevated plasma free fatty acid and BHB concentrations and decreased energy balance were related to decreased LP. This relationship was not surprising, because increased plasma free fatty acid and BHB concentrations and more severe negative energy balance were associated with increased PY, and consequently with decreased LP.

Dietary energy source in early lactation did not influence lactation curve characteristics, although a glucogenic diet improved metabolic status compared with a lipogenic diet in the second lactation of the present study (Chen et al., 2016). Boerman et al., (2015) reported increased milk yield with a high-starch (glucogenic) diet, but reduced milk fat yield compared with a high-fiber and high-fat (lipogenic) diet in mid-lactation cows (64 to 142 DIM). In line with this, we also found that a glucogenic diet tended to increase milk yield in the first 9 wk (Chen et al., 2016), but FPCM yield did not differ between diets, because the glucogenic diet decreased milk fat yield in the second lactation. In addition, the lipogenic or glucogenic diet was supplied only in the first 100 DIM in the present study. The fat and protein correction of milk yield and the limited period of dietary treatment may be related to the lack of difference on FPCM lactation curve characteristics between diets in the present study.

\section{CONCLUSIONS}

Shortening the DP to $30 \mathrm{~d}$ or omitting it altogether affected lactation curve characteristics in 2 subsequent lactations after implementation of DP length treatments in dairy cows, indicated by later PT, lower PY, and lower $\mathrm{FPCM}_{305}$ compared with a conventional DP of $60 \mathrm{~d}$. These effects were more pronounced in the first lactation following DP length treatments than in the second lactation, and more pronounced in parity $=2$ cows than parity $>2$ cows. Dry period length had no effects on LP in either lactation. Considering 2 lactations after implementation of DP length treatments, shortening or omitting the DP did not compromise FPCM yield compared with a conventional DP in parity $>2$ cows. In parity $=2$ cows, omitting the DP decreased the total FPCM yield throughout 2 subsequent lactations. Metabolic status in early lactation was related to the shape of lactation curve, although relationships were dependent on DP length. Severe negative energy balance and poor metabolic status were related to elevated PY, $\mathrm{FPCM}_{305}$, and low LP, especially in cows after a shortened or omitted DP.

\section{ACKNOWLEDGMENTS}

The authors thank the Dutch Dairy Board (PZ, the Netherlands), Product Board Animal Feed (PDV; the Netherlands), and CRV (the Netherlands) for financing the experiment. The authors thank the Chinese Scholarship Council for financial support. The authors thank the staff of the Dairy Campus (Lelystad, the Netherlands) and Veterinary Physiology Group of the University of Bern (Switzerland) for their technical support and laboratory analyses during the experiment.

\section{REFERENCES}

Annen, E. L., R. J. Collier, M. A. McGuire, J. L. Vicini, J. M. Ballam, and M. J. Lormore. 2004. Effect of modified dry period lengths and bovine somatotropin on yield and composition of milk from dairy cows. J. Dairy Sci. 87:3746-3761. http://dx.doi.org/10.3168/ jds.S0022-0302(04)73513-4.

Annen, E. L., A. C. Fitzgerald, P. C. Gentry, M. A. McGuire, A. V. Capuco, L. H. Baumgard, and R. J. Collier. 2007. Effect of continuous milking and bovine somatotropin supplementation on mammary epithelial cell turnover. J. Dairy Sci. 90:165-183. http:// dx.doi.org/10.3168/jds.S0022-0302(07)72618-8.

Annen, E. L., C. M. Stiening, B. A. Crooker, A. C. Fitzgerald, and R. J. Collier. 2008. Effect of continuous milking and prostaglandin E2 on milk production and mammary epithelial cell turnover, ultrastructure, and gene expression1. J. Anim. Sci. 86:1132-1144. http://dx.doi.org/10.2527/jas.2007-0726.

Appuhamy, J. A. D. R. N., B. G. Cassell, C. D. Dechow, and J. B. Cole. 2007. Phenotypic relationships of common health disorders in dairy cows to lactation persistency estimated from daily milk weights. J. Dairy Sci. 90:4424-4434. http://dx.doi.org/10.3168/ jds.2007-0077.

Arnold, P. T. D., and R. B. Becker. 1936. Influence of preceding dry period and of mineral supplement on lactation. J. Dairy Sci. 19:257-266. http://dx.doi.org/10.3168/jds.S0022-0302(36)930618.

Atashi, H., M. J. Zamiri, and M. Dadpasand. 2013. Association between dry period length and lactation performance, lactation curve, calf birth weight, and dystocia in Holstein dairy cows in Iran. J. Dairy Sci. 96:3632-3638. http://dx.doi.org/10.3168/jds.2012-5943.

Bernier-Dodier, P., C. L. Girard, B. G. Talbot, and P. Lacasse. 2011. Effect of dry period management on mammary gland function and its endocrine regulation in dairy cows. J. Dairy Sci. 94:4922-4936. http://dx.doi.org/10.3168/jds.2010-4116.

Boerman, J. P., S. B. Potts, M. J. VandeHaar, and A. L. Lock. 2015. Effects of partly replacing dietary starch with fiber and fat on milk production and energy partitioning. J. Dairy Sci. 98:7264-7276. http://dx.doi.org/10.3168/jds.2015-9467.

Capuco, A. V., R. M. Akers, and J. J. Smith. 1997. Mammary growth in Holstein cows during the dry period: Quantification of nucleic acids and histology. J. Dairy Sci. 80:477-487. http://dx.doi. org/10.3168/jds.S0022-0302(97)75960-5.

Capuco, A. V., D. L. Wood, R. Baldwin, K. McLeod, and M. J. Paape 2001. Mammary cell number, proliferation, and apoptosis during a bovine lactation: Relation to milk production and effect of bST1. J. Dairy Sci. 84:2177-2187. http://dx.doi.org/10.3168/jds.S00220302(01)74664-4. 
Chen, J., J. J. Gross, H. A. van Dorland, G. J. Remmelink, R. M. Bruckmaier, B. Kemp, and A. T. M. van Knegsel. 2015a. Effects of dry period length and dietary energy source on metabolic status and hepatic gene expression of dairy cows in early lactation. J. Dairy Sci. 98:1033-1045. http://dx.doi.org/10.3168/jds.2014-8612.

Chen, J., G. J. Remmelink, J. J. Gross, R. M. Bruckmaier, B. Kemp, and A. T. M. van Knegsel. 2016. Effects of dry period length and dietary energy source on milk yield, energy balance, and metabolic status of dairy cows over 2 consecutive years: Effects in the second year. J. Dairy Sci. 99:4826-4838. http://dx.doi.org/10.3168/ jds.2015-10742.

Chen, J., N. M. Soede, H. A. van Dorland, G. J. Remmelink, R. M. Bruckmaier, B. Kemp, and A. T. M. van Knegsel. 2015b. Relationship between metabolism and ovarian activity in dairy cows with different dry period lengths. Theriogenology 84:1387-1396. http:// dx.doi.org/10.1016/j.theriogenology.2015.07.025.

Collier, R. J., E. L. Annen-Dawson, and A. Pezeshki. 2012. Effects of continuous lactation and short dry periods on mammary function and animal health. Animal 6:403-414. http://dx.doi.org/10.1017/ S1751731111002461.

CVB. (Centraal Veevoederbureau). 2005. Veevoedertabel. Gegevens over chemische samenstelling, verteerbaarheid en voederwaarde van voedermiddelen. CVB, Lelystad, the Netherlands.

CVB. (Centraal Veevoederbureau). 2012. Tabellenboek Veevoeding 2012. Voedernormen landbouwhuisdieren en voederwaarde veevoeders. Productschap Diervoeder, Den Haag, the Netherlands.

Duffield, T. F., K. D. Lissemore, B. W. McBride, and K. E. Leslie. 2009. Impact of hyperketonemia in early lactation dairy cows on health and production. J. Dairy Sci. 92:571-580. http://dx.doi. org/10.3168/jds.2008-1507.

Hostens, M., J. Ehrlich, B. Van Ranst, and G. Opsomer. 2012. Onfarm evaluation of the effect of metabolic diseases on the shape of the lactation curve in dairy cows through the MilkBot lactation model. J. Dairy Sci. 95:2988-3007. http://dx.doi.org/10.3168/ jds.2011-4791.

Kok, A., C. E. van Middelaar, B. Engel, A. T. M. van Knegsel, H. Hogeveen, B. Kemp, and I. J. M. de Boer. 2016. Effective lactation yield: A measure to compare milk yield between cows with different dry period lengths. J. Dairy Sci. 99:2956-2966. http://dx.doi. org/10.3168/jds.2015-10559.

Mantovani, R., L. Marinelli, L. Bailoni, G. Gabai, and G. Bittante. 2010. Omission of dry period and effects on the subsequent lactation curve and on milk quality around calving in Italian Holstein cows. Ital. J. Anim. Sci. 9:101-108.

Miller, N., L. Delbecchi, D. Petitclerc, G. F. Wagner, B. G. Talbot, and P. Lacasse. 2006. Effect of stage of lactation and parity on mammary gland cell renewal. J. Dairy Sci. 89:4669-4677. http:// dx.doi.org/10.3168/jds.S0022-0302(06)72517-6.

Ospina, P. A., D. V. Nydam, T. Stokol, and T. R. Overton. 2010. Associations of elevated nonesterified fatty acids and $\beta$-hydroxybutyrate concentrations with early lactation reproductive performance and milk production in transition dairy cattle in the northeastern United States. J. Dairy Sci. 93:1596-1603. http://dx.doi.org/10.3168/ jds.2009-2852.

Rastani, R. R., R. R. Grummer, S. J. Bertics, A. Gümen, M. C. Wiltbank, D. G. Mashek, and M. C. Schwab. 2005. Reducing dry period length to simplify feeding transition cows: Milk production, energy balance, and metabolic profiles. J. Dairy Sci. 88:1004-1014. http://dx.doi.org/10.3168/jds.S0022-0302(05)72768-5.
Remond, B., J. Rouel, N. Pinson, and S. Jabet. 1997. An attempt to omit the dry period over three consecutive lactations in dairy cows. Ann. Zootech. 46:399-408.

Santschi, D. E., D. M. Lefebvre, R. I. Cue, C. L. Girard, and D. Pellerin. 2011. Complete lactation milk and component yields following a short (35-d) or a conventional (60-d) dry period management strategy in commercial Holstein herds. J. Dairy Sci. 94:2302-2311. http://dx.doi.org/10.3168/jds.2010-3594.

Steeneveld, W., Y. H. Schukken, A. T. M. van Knegsel, and H. Hogeveen. 2013. Effect of different dry period lengths on milk production and somatic cell count in subsequent lactations in commercial Dutch dairy herds. J. Dairy Sci. 96:2988-3001. http://dx.doi. org/10.3168/jds.2012-6297.

Van Es, A. J. H. 1975. Feed evaluation for dairy cows. Livest. Prod. Sci. 2:95-107. http://dx.doi.org/10.1016/0301-6226(75)90029-9.

van Knegsel, A. T. M., G. J. Remmelink, S. Jorjong, V. Fievez, and B. Kemp. 2014. Effect of dry period length and dietary energy source on energy balance, milk yield, and milk composition of dairy cows. J. Dairy Sci. 97:1499-1512. http://dx.doi.org/10.3168/jds.20137391.

van Knegsel, A. T. M., H. van den Brand, J. Dijkstra, W. M. van Straalen, R. Jorritsma, S. Tamminga, and B. Kemp. 2007. Effect of glucogenic vs. lipogenic diets on energy balance, blood metabolites, and reproduction in primiparous and multiparous dairy cows in early lactation. J. Dairy Sci. 90:3397-3409. http://dx.doi. org $/ 10.3168 /$ jds.2006-837.

van Knegsel, A. T. M., S. G. A. van der Drift, J. Čermáková, and B. Kemp. 2013. Effects of shortening the dry period of dairy cows on milk production, energy balance, health, and fertility: A systematic review. Vet. J. 198:707-713. http://dx.doi.org/10.1016/j. tvjl.2013.10.005.

Vance, E. R., C. P. Ferris, C. T. Elliott, S. A. McGettrick, and D. J. Kilpatrick. 2012. Food intake, milk production, and tissue changes of Holstein-Friesian and Jersey $\times$ Holstein-Friesian dairy cows within a medium-input grazing system and a high-input total confinement system. J. Dairy Sci. 95:1527-1544. http://dx.doi. org/10.3168/jds.2011-4410.

Watters, R. D., J. N. Guenther, A. E. Brickner, R. R. Rastani, P. M. Crump, P. W. Clark, and R. R. Grummer. 2008. Effects of dry period length on milk production and health of dairy cattle. J. Dairy Sci. 91:2595-2603. http://dx.doi.org/10.3168/jds.2007-0615.

Watters, R. D., M. C. Wiltbank, J. N. Guenther, A. E. Brickner, R. R. Rastani, P. M. Fricke, and R. R. Grummer. 2009. Effect of dry period length on reproduction during the subsequent lactation. J. Dairy Sci. 92:3081-3090. http://dx.doi.org/10.3168/jds.2008-1294.

Wilmink, J. B. M. 1987. Adjustment of test-day milk, fat and protein yield for age, season and stage of lactation. Livest. Prod. Sci. 16:335-348. http://dx.doi.org/10.1016/0301-6226(87)90003-0.

Wittrock, J. M., K. L. Proudfoot, D. M. Weary, and M. A. G. von Keyserlingk. 2011. Short communication: Metritis affects milk production and cull rate of Holstein multiparous and primiparous dairy cows differently. J. Dairy Sci. 94:2408-2412. http://dx.doi. org/10.3168/jds.2010-3697.

Zobel, G., D. M. Weary, K. E. Leslie, and M. A. G. von Keyserlingk. 2015. Invited review: Cessation of lactation: Effects on animal welfare. J. Dairy Sci. 98:8263-8277. http://dx.doi.org/10.3168/ jds.2015-9617. 